\title{
Shifting Paradigm? Long-Term Value Creation as a Normative Principle in a Hostile Takeover: Evidence from the Netherlands
}

\author{
N.T. Pham, T.L.M Verdoes
}

M.L. Lycklama a Nijeholt

J. Nijland

Department of Corporate Law and department of Business Studies,

Faculty of Law, Leiden University.

The authors thank Morshed Mannan and Thijs de Lange for valuable contributions.

Abstract

This article provides additional insight on the effectiveness of long-term value creation as a legally enforceable norm in the corporate governance system and provides a framework to anchor long-term value creation in takeover decisions. Since the 2008 financial crisis, a growing number of voices in the business world, government and academia, have urged Western economies to move towards a long-term sustainable growth agenda. Boards have a vital part to play in the development of responsible companies. Corporate governance should encourage boards to do so. This could be viewed as a reaction to the negative effects of capital markets and the resulting short-termism. One key method to encourage sustainable value creation in companies is by incorporating long-term value creation as an open norm in corporate governance systems. In the case of a hostile takeover, the risk of short-termism is exacerbated. As a guiding principle, long-term value (LTV) creation should prevent hostile takeovers that could harm the success of the company concerned. In this research paper, we argue that the recent shift in Dutch case law and revision of the Corporate Governance Code in the Netherlands may serve as an important catalyst for 'sustainable' takeover decisions. Through ground-breaking judgments by the Dutch Supreme Court and Enterprise Court, Cancun and Akzo Nobel, LTV has acquired the status of an enforceable norm. We investigated whether this legal norm is empirically substantiated. The research results allow us to make well-grounded statements about the effectiveness of enforcing LTV in future hostile takeover situations.

Keywords Long-term value creation, Takeover, Corporate governance, Normative principles, Stakeholder, Shareholder, Entity concept.

\section{Introduction}

Hostile takeovers continue to be at the centre of corporate governance debates. We address the debate with a closer look at the purpose and the interest of the company and how these concepts affect Dutch corporate governance. Moreover, we argue that the concept of company interest in creating long-term value creation, as a legally enforceable norm, might be a promising perspective to overcome the shareholder/stakeholder dichotomy in corporate governance debates. Furthermore, we argue that recognising the characteristics of company interest is an important step in making progress in this discourse.

We will start this paper with reflections drawing from economic literature on capital markets and theory of the firm that have provoked the need to revive the 'company interest' in the corporate governance debate. We argue that capital markets have become increasingly short-term oriented or less patient, which could be detrimental to long-term value creation. ${ }^{1}$ This problem is particularly acute in a hostile takeover situation. We have taken the Netherlands as a case study to investigate how well long-term value creation is grounded in the Dutch corporate governance system. We have conducted the case

${ }^{1}$ Graham et al. (2005), Barton, et al. (2016), Serafeim, et al. (2017), Barton (2017). For an opposite view, see Kaplan (2017). 
study by, first, systematically reviewing the body of case law produced by Dutch courts from 1971 to 2017 . Secondly, we have conducted in-depth interviews with the most prominent decision-makers in takeover conflicts. We coded the important and relevant recurring themes in the case law and the interviews and clustered them. In the paper, we synthesize these themes, showing a more accurate conceptualization of the company, the firm, and the positioning of takeovers in the corporate governance system. We conclude by discussing the relevance of anchoring long-term value creation in corporate governance systems.

\section{Economic reflections}

Corporate governance systems all share underlying ideas, ideologies and/or theories about the purpose of the company and its stakeholders and how these are related to capital markets. Governance systems can improve the functioning of the capital market, even make the functioning possible, but governance systems can also have the effect of hampering the performance of capital markets. This depends on how we conceptualize the capital markets, the company and the firm.

Capital markets, institutions and intermediaries are essential elements in our modern economic society. Ideally, a properly functioning and developed financial system can contribute to economic growth and prosperity if the flow of capital is efficiently organized and contributes to value increasing activities. There is a strong belief that capital markets contribute to the long-term value creating process of companies and societies. This belief depends heavily on an ideal type characteristic of capital markets: their efficiency. In an efficient capital market, prices fully reflect all relevant information (Fama, 1970: 383-417) and market prices are the best available estimate of the fundamental value of the relevant assets. In the Kay-Review (Kay, 2012: 71) it was recognised that the central focus of regulators has been on fighting specific abuses, reporting misleading information, fraud, conflicts of interest and foreknowledge; these could all be labelled as information asymmetries. ${ }^{1}$ The efficient market hypotheses became the ideological underpinning for governance purposes to eliminate these market failures.

One related belief is that the company is considered to be an extension of its shareholders (Fox and Lorsch, 2012). Anonymous shareholders are considered to be perfect and efficient monitors of managers. If a company moves away from shareholder wealth maximization, it will be disciplined by the market, because shareholders will sell the shares of the company. This will decrease the value of the shares, which will make a company more amenable for a (hostile) takeover. The company is thus disciplined beforehand. The concept of shareholder value thus provides timely, relevant and reliable financial information to diminish information asymmetries (Kay, 2012: 71).

If the capital market is efficient 'there is nothing to worry about'. Market efficiency implies that the conflict between short and long term, and between shareholder value and stakeholder value are non-existent. An efficient capital market takes future consequences and future reactions of other stakeholders into account. There are however important developments ${ }^{2}$ that undermine the central tenet of the efficient market hypotheses. ${ }^{3}$ In general, capital markets have become more international, pluralistic, anonymous and diffuse. Due to an increase in specialization and number of intermediaries, the equity-investment-chain has become larger, and changed from a relation-based to a transaction-based model. Within this chain, agents are frequently monitored with the use of benchmarks. The capital markets financing function is very low; their main function seems to be offering liquidity to larger multinationals exclusively (Eumedion, 2014). There are serious doubts whether the capital market performs its basic functions as a monitor and valuator and thereby improves long-term value creation. Moreover, would an efficient capital market reflect the underlying fundamental value - the long-term value - of the company and its affiliated firm? This question cannot be easily answered. The essence of long-term value creation is that this value, in principle, is unknown (Pitelis and Teece, 2009: 5-15). Value creation and the sustainability of a firm are the outcome of an uncertain market process - it depends on numerous interacting factors. Paradoxically, if the future value created by the company and its affiliated firm can be determined beforehand, it cannot be created anymore. Everybody then would know the details of its creation, while value creation could only occur when the origin - the idea - is

\footnotetext{
1 The upswing of the 'shareholder value' movement is usually assigned to Jensen and Meckling (1976), see Fox and Lorsch (2012). 2 Number of listed companies has declined from 160 (2003) to 97 (2013); relative importance of foreign investors has increased from $37 \%$ (1995), $70 \%$ (2007) to 76\% (2010); pension funds increasingly invest indirectly via intermediaries; this relative amount increases from $39 \%$ (2006) to $82 \%$ (2012), (Eumedion, 2014). Number of corporate takeover defenses decreased substantially (Bootsma, 2015); Average holding period of shares has decreased due to anonymous computerized trading (Haldane, 2010); Level of concentration of ownership declined from $34.6 \%$ to $24.1 \%$ during $2006-2016$ (de Jong, 2017).

${ }^{3}$ See Haldane (2010) for a lot of anomalies of the EMH.
} 
kept secret. Amit and Schoemaker (1993) recognize the following characteristics of valuable resources: complementary, scarcity, low tradability, inimitability, limited substitutability, appropriability, durability, and overlap with strategic industry factors. Bowman and Ambrosini (2007: 321-322) conclude that value depends on a complex pattern of interlinked, contextspecific factors, and a single resource is unlikely to be isolatable as the sole source of firm performance: "due to the many difficulties resources will resist any attempt at precise valuation."

Accordingly, if we are suspicious of whether the efficient market hypotheses is a suitable, sole or overarching mechanism to open up Pandora's box of a value creating firm, we should also critically reposition takeovers as a value enhancing mechanism and reassess the underlying corporate governance system. We propose that such reassessment should focus on the company and its affiliated firm(s) as a separate entity, moving beyond the classical dichotomy of shareholder and stakeholder orientation. ${ }^{1}$

\section{Beyond shareholder and stakeholder orientation: the company interest in hostile takeovers}

The significance of legal fiction

A firm (or enterprise) ${ }^{2}$ is an organized economic activity. Large firms are typically organised using companies which allow them to operate in the legal system and the economy and which structure their economic activities (Robé, 2011: 3).

A company and its affiliated firm can function in the economy as if it is a human being. Of course, it is true that companies are legal fictions. Even so, companies are significant 'fictions' and (the consequences of their actions - always done or committed by natural persons - are in principle attributed to these fictions by law. Companies protect the illiquid irreversible investments in the firm, to reap the benefits or capture the value created by the firm. By creating liquid markets, individual shareholders can exit on a daily basis and the company can transcend the time horizon of individual shareholders. ${ }^{3}$ Moreover, the company can transcend the time horizon of any other stakeholder making a contribution to the firm. The notion that companies are legal persons and are able to structure the economic activities of firms is of tremendous importance for the understanding of their governance.

\section{Company purpose}

The first key structuring element is that a company has a purpose. For each legal person under Dutch private law (i.e. the company), the law requires a purpose to be specified. It requires that the deed of incorporation contains the articles of association of the company and that these articles of association contain the purpose of the company. ${ }^{4}$ At its core, the purpose of the company is simply to develop certain activities to achieve certain results (Assink, 2015). Many legal systems, adopt an open-ended and value-neutral approach to the purpose of the company. To put it differently, there is no company law rule which requires that the purpose of a company is to direct its activities towards shareholder value maximization for the short or long term. ${ }^{5}$ Likewise, companies are under no legal obligation to advance wider, social, environmental, religious and/or public objectives. Admittedly, the company and its activities can be restricted via specific laws and regulations, for instance, securities law, tax law, labour law, environmental law, telecom law, energy law, and health care law. In those cases, the company must abide by these specific laws. However, to comply with specific laws is clearly distinct from incorporating a purpose wider than profit maximization, such as the care for the environment. In the latter situation, company law allows a company to internalize environmental care (or any other wider orientation) as part of its purpose by anchoring such purpose voluntarily in the articles of association.

\section{Company's interest and the interest of the firm}

The second key structuring element is that a company has a distinct interest. The notion that a company is a legal person with a definable purpose is accompanied with the acknowledgment that the company could be seen as an actor with its own interest, to be distinguished from those involved in or who have a stake in the company and its activities. The view that company interest could exist, distinct from the interests of the stakeholders of the company, applies best in the situation

\footnotetext{
${ }^{1}$ In the 1930's Berle and Dodd were already debating about the ontological existence of the firm as a separate entity (Robé, 2011).

${ }^{2}$ In this article firms and enterprise are used interchangeably to denote the organized economic activities that may be structured by companies.

3 The origin of the corporation - to stress the long term perspective - contradicts with the short term pressure of equity markets.

${ }^{4}$ Compare article 2:66/177 of the Dutch Civil Code (DCC) and section 31 of the UK Companies Act, 2006.

${ }^{5}$ For example, article 2:66(1) DCC.
} 
when a company maintains a firm. In a series of judgments in the takeover context, ${ }^{1}$ the Dutch Supreme Court explicitly acknowledged the distinction between the 'company interest' and the interests of 'others involved in the company'. Effectively, as we will demonstrate in section 3, the Supreme Court has consistently rendered its decisions based on the directors' obligation to act in the interest of the company and its affiliated firm (article 2:129/239(5) DCC, as codified in 2013), in conjunction with the standards of reasonableness and fairness to take due care of the interests of those involved in the company (article 2:8 DCC).

The growing body of case law in the Netherlands indicates that - although recognizing the open ended nature of the purposes companies may have - in the typical situation where a firm is connected to a company, the purpose of the company is to promote the interests of the firm. ${ }^{2}$ Yet, it was not until the Cancun judgment in 2014, that the Dutch Supreme Court explicitly assigned legal significance to the interest of the firm by interpreting the scope of the company's interest: 'if a firm is connected to a company, the company's interest is, as a general rule, mainly determined by promoting the sustainable success of this firm'. ${ }^{3}$ When treating this ruling formalistically, one could argue that the Supreme Court has attempted to define, or even to restrict, the interests of the company (Blanco Fernández, 2012, Raaijmakers, 2014). A closer reading suggests that the Supreme Court may not have intended such a narrow view. It is more likely that the Supreme Court's decision was intended to formulate a legal norm to rebut the absolute primacy of any single constituency's interests or entitlements, including the director's invested strategy in the firm. This argument may have greater substance, considering our understanding and deployment of the corporate entity and its affiliated firm in daily business and transitionary circumstances (Whincop, 2001: p. 48-49). Most companies are established for an indefinite period of time and operate in a changing environment. Not only do the external circumstances change over time forcing the company to make transitions, those involved in the company - the stakeholders - change too, sometimes within a split second.

That is not to deny that the ruling of the Supreme Court is without any effect. On the contrary. After Cancun, the amended Dutch Corporate Governance Code 2016 (DCGC 2016) acknowledged that the purpose of the company was to create long-term value'. ${ }^{4}$ It is important to note here that before the amendments to the Code, from 2003 onwards, the view of the Corporate Governance Monitoring Committee was that 'a company endeavours to create long-term shareholder value [emphasize added]'. ${ }^{5}$ Moreover, in the recent high profile takeover contest between Akzo Nobel and PPG, the Dutch Enterprise Court applied the Cancun formula and decided that company boards are obliged to direct their actions towards 'the long-term value creation of the company and its affiliated firm'. ${ }^{6}$

Without negating the significance of the above-mentioned rulings and developments in the Netherlands, one could argue that in effect 'the Dutch' are now merely 'in sync' with the 'neighbouring Europeans'. Germany, Sweden, Norway, Denmark, Austria and Belgium, have long emphasised the company's sustainable value creation. ${ }^{7}$ The orientation of the company towards sustainable value creation is not difficult to justify given the increased importance of the social embedment of companies, in particular those companies maintaining large firms, operating across the world. The company's license to operate might well depend on the extent to which the company and its connecting firm(s) succeed in creating value, globally and locally (de Jongh, 2011: 3). The legal translation could be argued as follows: that the company's interest to create value is regarded as a legal norm which is addressed to the company, to the constituents of the company such as the board of directors, the supervisory board and the general meeting of shareholders, and any other stakeholder involved in the company and its affiliated firm. Accordingly, acknowledging the company's interest as a legally enforceable norm is not without consequence, nor does it leave the corporate governance debate unaffected. Three major principles should be

\footnotetext{
1 See section 4 of this paper.

2 See section 4 of this paper.

${ }^{3}$ Dutch Supreme Court, 2014 NJ 2014/286 (Cancun), paragraph 4.2.1. We will be introducing our own translations of the Dutch court judgments.

${ }^{4}$ See the preamble of de DCGC 2016 and article 1.1.1 (strategy for long-term value creation) of the Code.

5 See the preamble of the DCGC 2003, under paragraph 3.

${ }^{6}$ Dutch Enterprise Court 29 May 2017 ECLI:NL:GHAMS:2017:1965, paragraph 3.34 (Akzo/Nobel), JOR 2017/261 with annotation from C.D.J. Bulten.

${ }^{7}$ See the Corporate Governance Codes of these countries, article 4.1.1 (CGC 2017 Germany), article 3.1 (CGC 2016 Sweden), pages 32 and 48 (CGC 2014 Norway), art. 4 (Denmark 2017) preamble, article 26a (Austria 2018), preamble under paragraph 2, article 1.1 (Belgium 2009).
} 
contemplated to overcome the shareholder/stakeholder dichotomy and to make progress in the corporate governance debate:

The interest of the company in the sustainable success of its affiliated firm transcends any stakeholder and shareholder interests;

Executive directors, under the supervision of supervisory directors, have an obligation towards the company to make business decisions (including strategic decisions) to further pursue the sustainable success of the interest of the company and its affiliated firm ${ }^{1}$ and when making these business decisions have an obligation towards the company's stakeholders, including shareholders, to take due care and not cause unnecessary or disproportionate harm; ${ }^{2}$

The company's shareholders, when acting collectively in the general shareholders meeting in the pursuit of their (collective) interests, are bound via the standards of reasonableness and fairness, to not disproportionately harm the company's interest, under the penalty of deterioration of the shareholders' resolution. A situation where individual shareholders are confronted with a bid and are incentivized to put their private interests first, may legitimately face frustration of the bid by the target board.

We investigated the robustness of these principles in a hostile takeover situation. We reviewed the case law from 1971 to 2017 with the aim of testing how well rooted these principles are in the Dutch legal framework in situations where target boards resisted an uninvited proposal from a bidder to take over the target company and/or situations where target boards have withstood shareholder activism to overrule board strategies or to force the replacement of incumbent board members (section 3). ${ }^{3}$ In addition, we reflected on the results of the case law analysis by conducting eight interviews with participants who hold positions which can be regarded as highly influential in shaping Dutch corporate governance (section 4).

\section{Results of the case law analysis 1971-2017}

\section{Takeovers and the right of inquiry}

A few preliminary remarks on the structure and legal context of the case law analysis should be made to allow better insight into the results of the research. Takeover conflicts are mainly (not exclusively) reviewed through an inquiry procedure before the Enterprise Court, by submitting a request for an investigation into the policy and affairs of the legal person (article 2:350 DCC) under the review of the Supreme Court. The legal person - the company - is thus the object of review. Unlike the civil procedure, the inquiry procedure is not aimed at settling disputes of a pecuniary nature, but foremost to re-establish healthy relations within the company. Given the particularity of the inquiry procedure, the Enterprise Court may review the actions of company boards and of the company shareholders. We investigated whether in a hostile takeover situation longterm value creation was a determining factor for the courts ${ }^{4}$ to review and decide the takeover conflict. More specifically, we focused on finding the conditions and circumstances an anti-takeover defensive measure (ATD) taken by the company, by means of its target board, was allowed, or in legal terms, was justified. ${ }^{5}$ If an ATD was not justified, it might be an indication that mismanagement has taken place and that there are well-founded reasons to doubt that the company's policy or state of affairs was in order. In the cases under study, the judicial review was mainly focused on assessing the obligations of the company and its board in taken the decision to implement an ATD and whether this decision was justified. At the same time, we extrapolated our analysis to assess the duties of other stakeholders, namely those of the shareholders in a takeover situation.

Reasonableness and fairness as the dominant standard of review of target boards' decisions - 1971

In the earliest cases, courts reviewed anti-takeover defensive measures on the basis of reasonableness and fairness, without explicit mention of sustainability or long-term value creation. ${ }^{6}$ The starting point in early rulings has been that an

\footnotetext{
${ }^{1}$ Accordingly, exercising their legal task (article 2:129/239 DCC).

2 Accordingly, to abide by the standards of reasonableness and fairness (art. 2:8 DCC).

${ }^{3}$ The case law analysis ended on 1 December 2017.

${ }^{4}$ Referring to the Enterprise Court and/or the Supreme Court.

${ }^{5}$ Rb. Haarlem, 12 June 1990 ECLI:NL:RBHAA:1990:AC2566 (Asko/Ahold).

${ }^{6}$ Hof Amsterdam 1 April 1971, ECLI:NL:GHAMS:1971:AB6704 (Immofarm AG/NV Handelsvereening v/h Reiss en Co ea); Rb. Haarlem, 12 June 1990 ECLI:NL:RBHAA:1990:AC2566 (Asko/Ahold).
} 
ATD is justified if a company could 'reasonably expect a possible threat to its continuity and own identity'. ${ }^{1}$ This line of reasoning has been reaffirmed in later judgments. ${ }^{2}$

In Immofarm, the 'continuity of the company' and 'the autonomous existence of the company', 'the preservation of its own Dutch character and its staff were reasoned as part of the duties of the executive and supervisory board towards the company. These company interests were in the realm of director duties, acknowledged as legitimate interests that could justify ATDs. ${ }^{3}$ As the legitimacy of ATDs could depend on whether the continuity or identity of the company may be harmed, a target board's decision to establish an ATD under such conditions was regarded as not being contrary to what the standards of reasonableness and fairness dictate and therefore was not unlawful. ${ }^{4}$ Accordingly, the legal norm of reasonableness and fairness is first addressed to the company - without aforementioned justification, the acts of the company are contrary with 'reasonableness and fairness' - and second to the target board, whose obligation towards the company requires the target board to take defensive measures. Reasonableness and fairness thus delineates the leeway for target boards to take ATDs.

Company interest as a safe harbour for target boards - 1993

In the GTI Holding case, the GTI board issued shares to defeat a change of control. The ATD was justified, not only because the 'autonomous existence of the company and independence of the company' was under threat, but also because of concern for the 'wellbeing of the company'. ${ }^{5}$ The dispute involved a minority shareholder of a competing company who secretively enlarged his shareholding to $32 \%$, after the GTI board rejected his proposal to cooperate. In the GTI Holding judgment, the threat to the autonomous existence and independence of the company was objectively assessed as follows:

The acquirer or bidder has given evidence of hostile intentions with regard to gaining control e.g. against the wish of the board and supervisory board of the target company;

And the actions of the hostile party are a threat to the autonomous existence of the company and the independence of the company. The mere statement that the secretive acquisition of a larger shareholding was not done with bad intentions, does not take away that the company could perceive it as a threat. ${ }^{6}$

If these conditions are not met, the use of a target board's competence to establish an ATD are contrary to reasonableness and fairness, exposing the decision to annulment (article 2:15 DCC). In other words, a (threat to) the interest of the company serves as a safe harbour for target boards to take ATDs within the boundaries of reasonableness and fairness. ${ }^{7}$ This safe harbour argument can also be inferred from the Heineken Holding N.V. decision, ${ }^{8}$ which was rendered eight years after GTI Holding. Heineken explicitly defined the purpose of the company's interest to ensure the continuity of its group in the company's articles of association. Interestingly, the court ruled that when the main goal of a company is to ensure continuity, and this purpose is well known to the shareholders of the company, the shareholders cannot demand that the company will take extreme measures, such as the repurchase of its own shares, that would diminish its influence or even prompt its own liquidation, to increase shareholder value. ${ }^{9}$

The influence of the company's statutory structure on the interests of the company's stakeholders - 2003

In the landmark case RNA, rendered in 2003 , the Supreme Court further specified conditions for protecting the company interest. The (use of an) ATD must be temporary, so long as it is not found that the company interest is disproportionately harmed. Here, proportionality is understood as not going any further than required regarding the object of protection. ${ }^{10}$

\footnotetext{
1 Rb. Haarlem, 12 June 1990 ECLI:NL:RBHAA:1990:AC2566 (Asko/Ahold).

23 January 2009, JOR 2009 / 69 (Beheermaatschappij Trial).

${ }^{3}$ Hof Amsterdam (OK) 1 April 1971, ECLI:NL:GHAMS:1971:AB6704 (Immofarm AG/NV Handelsvereening v/h Reiss en Co ea).

${ }^{4}$ Rb. Haarlem, 12 June 1990 ECLI:NL:RBHAA:1990:AC2566 (Asko/Ahold).

${ }^{5}$ Rb Utrecht 15 September 1993 ECLI:NL:RBUTR:1993:AC4321 (GTI Holding).

${ }^{6}$ Rb Utrecht 15 September 1993 ECLI:NL:RBUTR:1993:AC4321 (GTI Holding), see consideration 5.8.

${ }^{7}$ Rb Utrecht 15 September 1993 ECLI:NL:RBUTR:1993:AC4321 (GTI Holding), see consideration 5.9.

${ }^{8}$ Hof Amsterdam (OK), 18 October 2001, ECLI:NL:GHAMS:2001:AD4646, NJ 2001, 641 (Heineken Holding NV).

${ }_{9}$ Hof Amsterdam (OK), 18 October 2001, ECLI:NL:GHAMS:2001:AD4646, NJ 2001, 641 (Heineken Holding NV).

${ }^{10}$ Compare Hof Amsterdam (OK) 5 August 2005, JOR 2005/241 (VIBA).
} 
Accordingly, the company's structure may be a relevant factor in determining the legitimacy of a target board's defensive measure, taking into account the position of (minority) shareholders.

The investment company, RNA, was confronted with cooperation plans from minority shareholder, Westfield, who exploited competing activities. ${ }^{1}$ Westfield wished for a special shareholders' meeting to discuss his plans, but RNA did not want to discuss Westfields' plans and set up a 'Stichting Belangenbehartiging Beleggers RNA' (SBBR) as an ATD. ${ }^{2}$ The Enterprise Court ruled that the fact that a minority shareholder can exercise a decisive influence due to an open statutory structure is in itself an insufficient justification for establishing an ATD and even more so when considering:

that the minority shareholder is an expert in the same sector as the legal person,

that this shareholder has the support of another important minority shareholder, ${ }^{3}$

that the legal person in question is an investment company with variable capital with the sole purpose of investing and spreading risk, so that other interests than that of the shareholders carry less weight.

The RNA case underlines the importance of the statutory structure and purpose of the company when deciding what the legitimate interests of the company and other stakeholders are. Accordingly, the legal structure of the company may raise reasonable expectations. However, despite the open structure of a company, a target board's decision to establish an ATD could nonetheless be justified based on the norms of reasonableness and fairness.

Going from stakeholder value to long-term value creation of the company - 2007- 2017

In the Stork decision, in 2007, it was for the first time ruled that company boards are obliged to take into account the interests of all stakeholders. ${ }^{4}$ More specifically, the Enterprise Court judged that Stork's board had legitimately taken the interests of all stakeholders into account, and not solely of shareholders, when it established the ATD. ${ }^{5}$ In this particular case, the relationship between the company's board and its shareholders, Centaurus and Paulson, both hedge funds, was distorted. Since the board has a primary responsibility for determining the company's strategy and had wide support for its successful strategy from important stakeholders, the Enterprise Court deemed the board's strategy to be sound. Accordingly, Stork was not obligated or could not be forced to abandon its stand-alone strategy and opt for the plans of Centaurus, which would involve high risks for all stakeholders. ${ }^{6}$

A few months later, finally, in the $A B N A M R O$ case, the Supreme Court, recognised that the company's interest and its affiliated firm's interest as being a distinct interest from those of the company's stakeholders. ${ }^{7}$ But it was not until 2014, in Cancun, that the Supreme Court rendered its progressive decision. The Court first clarified what the company's interest may encompass if there was a firm connected to the company, which is 'to promote the sustainable success of the company'. Second, that the company interest is a separate, distinct interest from the interest of the company's stakeholders. And third, that a company board, first and foremost owes its duty to the company to promote the interest of the company and its affiliated firm. While discharging this legal obligation, the board has to take into account the interests of the company stakeholders according to the requirements of reasonableness and fairness.

Three years later, Cancun was put to an ultimate test. In the Akzo Nobel decision, the Enterprise Court reinforced Cancun and gave legal effect to the revised Corporate Governance Code. The memorable ruling is as follows: 'in the face of propositions of a potential bidder, the board of the company has to focus on - in the terms of the Corporate Governance

\footnotetext{
1 Hof Amsterdam (OK), 16 October 2001 (ECLI:NL:GHAMS:2001:AD4598), NJ 2001, 640 (Westfield Limited ACN/Rodamco North America NV).

2 Hof Amsterdam (OK), 16 October 2001, ECLI:NL:GHAMS:2001:AD4598), NJ 2001, 640 (Westfield Limited ACN /Rodamco North America NV), see point 3.7.

3 Hof Amsterdam (OK), 16 October 2001, ECLI:NL:GHAMS:2001:AD4598), NJ 2001, 640 (Westfield Limited ACN /Rodamco North America NV), see point 3.13.

${ }^{4}$ Hof Amsterdam (OK), 17 January 2007, ECLI:NL:GHAMS:2007:AZ6440 (Stork), 3.16-3.17.

${ }^{5}$ Hof Amsterdam (OK), 17 January 2007, ECLI:NL:GHAMS:2007:AZ6440 (Stork), 3.16-3.17.

${ }^{6}$ Hof Amsterdam (OK) 17 January 2007, ECLI:NL:GHAMS:2007:AZ6440, (Stork), see consideration 3.16-3.17 and HR 13 July

2007,ECLI:NL:HR:2007:BA7972; NJ 2007, 434 (ABN AMRO),ECLI:NL:PHR:2007:BA7972.

${ }^{7}$ HR 14 July 2007, ECLINL:HR:2007:BA7972, (ABN AMRO) 3.14.
} 
Code - the long term value creation of the company and its connecting firm and to weigh the interests of all relevant stakeholders. ${ }^{1}$

One could argue that the importance of the company's interest and its firm has gained importance, even legal significance; and as was shown in Akzo Nobel, the capability of being legally enforced. The evolution in case law in takeover conflicts shows very clearly the distinct characteristics of Dutch Corporate Governance. The prevalence of the company's interest demonstrates that it is inaccurate to continue to narrow the corporate governance debate to a shareholder/stakeholder dichotomy. Persisting in such conventional thinking is denying the fundamental revolution in company law, which to a greater or lesser extent, is already manifest worldwide (Timmerman, 2014). ${ }^{2}$

\section{Results of the interviews}

\section{In-depth interviews}

This section contains the results of eight interviews. We asked participants to reflect on some major takeover conflicts, international developments in corporate governance, recent court decisions and the adoption of long-term value creation of the company and its connecting firm in the Dutch corporate governance system. Among the participants were some key executive and supervisory directors, judges from the Dutch Supreme Court and the Enterprise Court, an Advocate General, a member of the Corporate Governance Monitoring Committee and institutional investors. The interviews were conducted in spring 2018 and lasted about an hour to an hour and a half. The interviews were in-depth interviews to allow the participants to speak freely about a number of themes based on their roles, experiences and preferences. All interviews have been tape-recorded and transcribed. Interviewees have been promised anonymity. The next sections contain ideas and opinions of the participants clustered by different themes followed by a section in which we reflect on the main tradeoffs that can be derived from these themes.

When the legal and the social discourse on corporate governance coincide

Judges are not and do not proclaim to be a policy-making body. They prefer to refrain from entering into discussions about company interest, long-term value, sustainability, stakeholder or shareholder value - issues that the legislator should resolve. In addition, judges do not take a position on the company's policy - that is the prerogative of the company director, nor are judges inclined to scrutinize business decisions. Judges are bound by marginal judicial review on the basis of open norms. Both mechanisms are in place to respect the director's discretionary decision making power. The participants from the judiciary clearly stress that 'judges mainly follow, they do not form'. This statement should be viewed critically. In section 3, we have demonstrated that it is the cornerstone in Dutch company law, that company directors discharge their obligations in the interest of the company and its connecting firm. Company interest involves an open norm. Not only does the open norm allow directors discretion, it also allows judges discretion to properly apply the norm to a specific case at hand. Participants have argued that judges have simply applied and interpreted the open norm in Cancun and Akzo Nobel as was required within the boundaries of Dutch law:

"I think we can safely say that in the Netherlands, the stakeholder approach is prevalent. This affects the standard of company interest. There is some latitude when you explain the standard and I think that the social debate then plays a role...

Of course we have room to maneuver, but it is all within the limits of the law and when there is openness, you take account of the social debate. I myself think that if a Supreme Court says that the company interest is focused on the firm's success, it is not a view of the judge himself. It is something that the judge thinks: "Well, this seems now widely supported. It is the basis of Dutch law. We can safely say: The company's sustainable success"." (participant 2).

Indeed, for a judge, the assessment of the process is part of judicial review not the assessment of the content of a business decision. Judges examine which rules have been followed, which participants are involved in the process and whose interests have been considered. The company interest is used by the courts as a key to justify the choices made in the

\footnotetext{
1 See also Hof Amsterdam (OK), 29 May 2017, ECLI:NL:GHAMS:2017:1965 (AkzoNobel), see consideration 3.12.

2 Also in Anglo-American traditions, see Orts (2013: 109-131 and 175-222).
} 
process, as company interest is recorded in the law. Only if the board of directors exceeds the limits of company interest, the judge will retain company interest as the standard. In this case, the norm is addressed to the judge.

Company interest

Although it is the task of a board of directors to determine the company interest, we asked participants to reflect on factors that may be tested to determine whether the company's policy is in line with the company interest.

Several factors have been mentioned that may determine the company interest, including: the nature of the company (e.g. national security or national importance), principles laid down in the articles of association, and a clear picture of the company's stakeholders as well as their interests and the consequences of the takeover. Occurrences such as hostile takeover attempts may not cause disproportionate damage to the company interest. It could even be a safe line. Therefore, the target board must form a clear picture of what the consequences of the acquisition are for the company and its connecting firm, thereby taking into account employment opportunities, competition law, and synergies. Particularly in a calm period, each board should clearly formulate what the company interest involves, and which interests and policies are part of the company's interest, for instance the environmental and/or social policies. A clear formulation of the company interest by the board of directors could guarantee a credible story with any stakeholder of the company including shareholders in case of a hostile takeover attempt, and with the judge in case of a takeover conflict. As one of the participants puts it: "As a business, you have to be able to anticipate in stead of thinking in terms of anti-takeover measures. We have passed that time, it is not sustainable." (participant 5).

This statement is in line with the explanation of executive and supervisory directors. The participants indicated that during a hostile takeover, the board went through a list of conditions that had to meet the company interest. The list consisted, among others, a fair price, the interests of the company's stakeholders, and, where applicable, the national security and whether the bidder could be considered a bona fide bidder.

Although none of the participants could deny that shareholders have a strong position in an open public limited company, the majority of the participants agreed that a considered strategy which is plausible, defensible, up-to-date, adequately communicated and made transparent - showing the trade-offs - gives CEO's leeway to determine a long-term route to create long-term value by which it can sustain the business. The best protection of a company is not determined by sophisticated anti-takeover measures, but a sound and clear business policy and strategy that creates long-term value.

\section{Long-term value creation}

The corporate governance code was also brought to the attention to the participants. In particular, the fact that it states that the company must strive for long-term value creation, so that the interests of the company and its connecting firm are served.

A takeover can be the best option for the company and its connecting firm, especially in cases where a lot of investments for long-term stand-alone survival are needed and financing is doubtful. In taking a position in the takeover battle, the level of supposed added value is not the critical element, but how this added value is created. The central consideration is if the interests of stakeholders are not disproportionately harmed.

The general opinion was that concepts such as success of the firm, continuity of the firm and long-term value creation overlap. The meaning of long-term value was interpreted differently by the participants. Company boards tend to interpret long-term value creation as striking the right balance in the actions of the board of directors for the different stakeholders of the company.

Investors tend to view long-term value as more comprehensive than company interest. It also consists of Environmental, Social \& Governance (ESG) criteria of a company and other non-financial values. One of the participants also argued that ESG should be more clearly expressed in the long-term strategy of the company.

The present attitude, perceptions and discussion about shareholder-, stakeholder and/or long-term value is a response to the fear of the short-sighted pressure of the capital markets, and in special cases e.g. the ABN-Amro traumatic battle, which tore the company into three pieces and was severely detrimental to the national interest. Due to these forces, firms cannot or can to a lesser extent, implement sound business policies. One of the participants from the judiciary described this as a "sad state of affairs". Judges however cannot disclose all considerations in legal decisions. The legal attitude seems to 
be: "we are not going to co-operate with a hostile takeover, unless", which is only marginally reviewed. Judges seem also fear the consequences of their verdict because it can open the door to an uncontrollable process, which can be - due to capital market dynamics - irreversible. It seems that judges are inclined to slow down the process, so that a more balanced judgment can be made concerning trade-offs. The hostile takeover process is influenced by a lot of lobbying, by lawyers, banks, activist shareholders, and the company itself, according to participant 8.

Being a member of the Monitoring Committee, participant 7 stresses the importance of long-term value creation as an enforceable norm, particularly in the face of a hostile takeover. Hostile takeovers typically involve the absence of dialogue between target and bidder and due diligence. Incumbent boards will tend to resist access to due diligence when faced with an uninvited bid. The participant therefore asks boards to critically reflect on the question whether a hostile takeover is an appropriate instrument to create value for the business at all. Without dialogue and due diligence a bidder company could be exposed to excessive risks which may not be in the long-term interest of the bidder company.

\section{Broad support and critical voices}

The participants seem to support the importance of the adoption of long-term value creation as a norm. It is interesting to observe that investors express their broad support. As one of the participants remarks, shareholders seem to attach more value to long-term value creation than before. For instance, ESG criteria of a company are becoming more important in investment decisions of investors/shareholders. However, the participant stressed that the accountability of boards of directors and their companies on non-financial values can be further improved: "Investors want to be better informed and convinced about the long-term strategy. Not all boards of directors are sufficiently sharp and responsive. There are few good examples such as DSM, Philips, AMSL. They are at the forefront and therefore are able to avoid threats of activism." (participant 6).

Yet, there are also critical voices about long-term value creation as a norm. There is a risk that such an open norm would end up to be a panacea. Participant 6 argued that in a public bid situation, the shareholder should be in the driver's seat, not the board. According to the participant, long-term value creation should not play a role in a public bid situation. The participant argued that in the event of a takeover bid, there cannot be any going concern conception of the target company. The shareholders will base their decision to sell their shares on the price that is offered in a public bid situation. Therefore, the price offered should be the guideline for a target board. "Everything is accounted for in the price." Moreover, the participant believed that other factors, such as ESG indicators, are also included in the price mechanism.

The above view contrasts significantly with the view of judges. The company interest may differ from the interest of the shareholders to receive the highest price possible. Under Dutch law, target boards may lawfully decide against the shareholders' interests. As one of the participants stressed, if a firm is connected to a company, that company and its board are obliged to promote the long-term value of the company and its firm. It seems indeed that, at least from a legal perspective, long-term value creation has become a legally enforceable norm in a takeover situation. "That is what the court ruled". (participant 1).

\section{Reflection}

The communis opinio was that open norms have been gradually introduced to the Dutch hostile takeover market. Company and firm interest, long-term value creation, lasting success, sustainability and continuity have been established and consolidated as open norms in the Netherlands. Shareholder value - a hard one-dimensional norm - has been suppressed by long-term value creation - a soft multi-dimensional norm. Some participants suggested that this is a reaction to recent hostile takeovers that had sizable negative repercussions on the Dutch economy (for instance the ABN AMRO trauma). Others also connected this movement to the purported short-term pressure of capital markets. This was the standard reasoning in the past, when the norm - shareholder value maximisation - was based on principles of corporate finance and characteristics of capital markets. Institutional investors, however, still see a more important role for the capital market, even if it is conceded that open norms are now a fact of life. They should act in the interest of their constituents; and they have something to explain when they do not go for the highest bid.

Open norms are only limitedly enforceable. Executive directors are, in large part, autonomous in choosing a strategy. So, in principle, executive directors have the benefit of the doubt. Judges only marginally review a hostile takeover. The executive director is, in principle, the best equipped person to make such a decision. However, not every strategy is plausible, sustainable or feasible in the context of long-term value creation. An up-to-date strategy containing trade-offs 
may protect a company against hostile takeover attempts and provide executives room for action. This protection is not unlimited, because the strategy and the reaction to the offer have to be convincing. Company interest should not be confused with strategy. But judges sometimes feel that they have to pronounce a verdict. They fear the unknown consequences of a hostile takeover; there are high risks involved when a company changes their market/product portfolio. But of course not changing means that there are no risks. This also depends on the guarantees offered by the bidding company. Even when a stand-alone choice is not always the best option, judges may fear that an early opening of the door of negotiations sets an irreversible process in motion and careful consideration of the offer is no longer possible.

\section{Conclusion}

An important conclusion is that the dominant Anglo-American agency theory is not easily applicable in Dutch corporate governance. Agency theory assumes that the interests of the agents (directors and supervisory directors) do not always run parallel to those of the principals. Agents should not be trusted because they are continually tempted to make decisions in their own interest over those of the principal. There are alternative views on how we assume people behave however, for instance as one of the participants from the judiciary concisely commented: "I strongly believe in the mechanism of trust. I would rather be cheated now and then, instead of wanting to check everything. I also know that some people say 'trust is good, control is better'." The differences in the concept of mankind may have major consequences for the way corporate governance is structured and rationalised. In Anglo-American traditions, the communis opinio is that the shareholders are the ultimate principals. This stands in stark contrast with the Dutch pluralistic view. The company is the principal, so that directors and supervisory directors must direct their actions to further the company's interests. Recognising that shareholders' interests and company interests may differ has the implication that disciplining the management by shareholders does not necessary serve the interests of the company. This observation does not undermine or diminish the need to discipline executive and supervisory directors. It does however create more complex questions about what solutions are most appropriate. The 'Dutch' seem to no longer look at shareholder value, or the bid price in takeover situations, in isolation as it is simply a one-dimensional inaccurate measure of the value of the firm. Moreover, the belief in the efficiency of capital markets has been kept in check. The 'Dutch' have long learned from the 'ABN AMRO traum', that the pursuit of shareholder wealth could significantly harm the company's interests and society at large.

It seems that, as a consequence of the long-term value creation norm, a new conceptualisation of the company and the affiliated firm has emerged next to the shareholder and stakeholder view, as a reaction to less patient capital markets: the company as a real entity. As a result an alternative principal-agent model arises: the principal (company) and the agent (the board of directors). Long-term value creation changes the attachment of legal scholarship and business studies, and press both disciplines to (re)examine and (re)establish the company interest in the corporate governance debate.

\section{Literature}

[1] Assink, B.F. (2015). Belang van de vennootschap, overname en algemeen belang. WPNR 31 January 2015/7048.

[2] Barton, D. (2011). Capitalism for the long term. Harvard Business Review, https://hbr.org/2011/03/capitalismfor-the-long-term

[3] Barton, D., Bailey, J., and Zoffer, J. (2016). Rising to the challenge of short-termism. Focusing Capital on the Long Run (FCLT).

[4] Blanco Fernández, J.M. (2018). Wat is de vennootschap en wat behoort het vennootschapsrecht te zijn. Ondernemingsrecht 2018/29.

[5] Bowman, C., Ambrosini, V. (2003). What does value mean and how is it created, maintained and destroyed? Paper presented at the Academy of Management Meeting, Seattle.

[6] Eumedion, (2014). Corporate governance forum, Position paper, The future of the public equity market from the perspective of Dutch institutional investors.

[7] Fama, E.F. (1970). Efficient Capital Markets: A Review of Theory and Empirical Work. The Journal of Finance, Vol. 25, No. 2. pp. 383-417.

[8] Fox, J., and Lorsch, J.W. (2012). What good are shareholders? Harvard Business Review. https://hbr.org/2012/07/what-good-are-shareholders

[9] Graham, J.R., Harvey, C.R., and Rajgopal, S. (2005).The economic implications of corporate financial reporting. Journal of Accounting and Economics. Vol. 40. pp. 3-73.

[10] Haldane, A. (2010). Patience and finance, Speech at the Oxford China Business Forum, Beijing, 9 September. 
[11] Jensen, C., and Meckling, W. (1976). Theory of the Firm: Managerial Behavior, Agency Costs, and Capital Structure. Journal of Financial Economics, 3(4) pp. 305-360.

[12] Jong de, A. et al. (2017). Large Shareholders in Corporate Governance. Research for the Monitoring Committee Corporate Governance on the role of large shareholders in corporate governance in the Netherlands commissioned by the Ministry of Economic Affairs. RSM, Erasmus University Rotterdam.

[13] Jongh, de, J.M. (2011). 'Redelijkheid en billijkheid en het evenredigheidsbeginsel, in het bijzonder in de verhouding aan aandeelhouders tot het bestuur', Ondernemingsrecht 2011/124).

[14] Kaplan, S.N. (2017). Are U.S. Companies too short-term oriented? Some thoughts. NBER

[15] Kay, J. (2012). The Kay review of UK equity markets and long-term decision making.

[16] Orts, E.W. (2013). Business Persons, a Legal Theory of the Firm.

[17] Pitelis, C.N., and Teece, D.J. (2009). The (new) nature and essence of the firm, European Management Review, pp. 5-15.

[18] Raaijmakers, M.J.G.C. (2014). Cancun: een joint venture klem tussen contract en instituut. Ars Aequi. pp. 459465.

[19] Reisberg, A. (May 26, 2013). Shareholder Value after the Financial Crisis: A Dawn of a New Era? International Corporate Rescue 143. Available at SSRN: https://ssrn.com/abstract=2360125

[20] Rindova, V.P., and Fombrun, C.J., (Aug. 1999). Constructing Competitive Advantage: The Role of FirmConstituent Interactions. Strategic Management Journal, Vol. 20, No. 8. pp. 691-710.

[21] Robé, J-P. (2011). The Legal Structure of the Firm. Accounting, Economics, and Law, Vol. 1. pp. 1-86.

[22] Serafeim, G. et al. (2017). Moving Beyond Quarterly Guidance: A Relic of the Past. Focusing Capital on the long run $(\mathrm{FCLT})$.

[23] Whincop, M.J. (2001). An Economic and Jurisprudential Genealogy of Corporate Law, Dartmouth Publishing Co. Ltd.

[24] Working Paper 23464. http://www.nber.org/papers/w23464 